\title{
Antagonistic Activity of Panchagavya and Trichoderma spp. against Wilt Complex causing Pathogens of Chickpea (Cicer arietinum L.)
}

H.V. Parmar, N.M. Gohel

10.18805/IJARe.A-5922

\begin{abstract}
Background: Chickpea wilt complex caused by several soil-borne pathogens is the major yield-reducing malady worldwide. Biological control is one of the best, low-cost and ecologically sustainable method for managing plant diseases caused by soil-borne pathogens. Methods: In this present investigation Panchagavya and Trichoderma spp. were evaluated by following poisoned food technique and dual culture technique against wilt complex causing pathogens i.e. Fusarium oxysporum f. sp. ciceri, Fusarium solani and Macrophomina phaseolina.

Result: Among the different isolates of Trichoderma spp. evaluated, Trichoderma viride (AAU isolate) was highly antagonistic to $F$. oxysporum f. sp. ciceri (52.78\%) and $F$. solani $(65.37 \%$ ) whereas, Trichoderma asperellum (AAU isolate) was highly antagonistic to $M$. phaseolina (65.93\%). Panchagavya at the highest concentration (50\%) showed significantly higher efficacy $(80.74,66.62$ and $49.67 \%)$ in inhibiting the mycelial growth of all three pathogens and at the lowest concentration it was moderately effective.

Key words: Biological control, Chickpea wilt complex, Fusarium oxysporum, Fusarium solani, Macrophomina phaseolina, Panchagavya, Trichoderma.
\end{abstract}

\section{INTRODUCTION}

Chickpea (Cicer arietinum L.) occupies an important place in the pulse production and India is the largest producer of chickpea in the world. About 172 pathogens including 67 fungi, 3 bacteria, 22 viruses and 80 nematodes have been reported infecting chickpea world-wide (Nene et al., 1996), out of which 89 have been reported from India alone (Cother, 1977).

Among these, wilt complex caused by several soilborne pathogens is one of the most destructive diseases of chickpea. Biological management has been proved to be an effective and safer alternative to hazardous agrochemicals against these soil-borne pathogens.

Panchagavya, an ancient preparation has been used to enhance the plant growth and resistance to diseases in traditional agricultural systems in India (Munshi, 1964). It increases the immunity of plants, thus the plants will be able to resist pests and diseases (Natarajan, 2002). While, among the various biocontrol agents Trichoderma spp. has been widely studied for their biocontrol ability (Sharma et al., 2014). Keeping this in view, the present investigation was carried to assess the efficiency of Panchagavya and Trichoderma spp. against wilt complex causing pathogens i.e. F. oxysporum f. sp. ciceri, F. solani and M. phaseolina in vitro.

\section{MATERIALS AND METHODS}

The experiment was carried out at the Department of Plant Pathology, B. A. College of Agriculture, AAU, Anand. The pathogens viz., F. oxysporum f. sp. ciceri, F. solani and $M$. phaseolina were isolated from infected chickpea plants on Potato Dextrose Agar (PDA) medium.
Department of Plant Pathology, B.A. College of Agriculture, Anand Agricultural University, Anand-388 110, Gujarat, India.

Corresponding Author: H.V. Parmar, Department of Plant Pathology, B.A. College of Agriculture, Anand Agricultural University, Anand-388 110, Gujarat, India. Email: harshilprmr@gmail.com

How to cite this article: Parmar, H.V. and Gohel, N.M. (2022). Antagonistic Activity of Panchagavya and Trichoderma spp. against Wilt Complex causing Pathogens of Chickpea (Cicer arietinum L.). Indian Journal of Agricultural Research. DOI: 10.18805/IJARe.A5922.

Submitted: 29-09-2021 Accepted: 20-12-2021 Online: 14-01-2022

\section{Panchagavya}

The effect of panchagavya was studied against all three pathogens separately at different concentrations i.e. 10, 20, 30,40 and $50 \%$ using poisoned food technique given by Grover and Moore (1962). Three repetitions were kept for each concentration. The observation on the linear growth of the fungus was recorded until the entire plate in control was completely covered with mycelium. The per cent growth inhibition (PGI) over control was calculated by using the formula given by Vincent (1947).

Where,

$$
P G I=\frac{D C-D T}{D C} \times 100
$$

DC $($ Diameter of control $)=$ Mean diameter of mycelial colony in control treatment $(\mathrm{mm})$.

DT $($ Diameter of treatment $)=$ Mean diameter of mycelial colony in treated set $(\mathrm{mm})$. 


\section{Preparation of panchagavya}

Panchagavya was prepared by the following method developed by the National Centre of Organic Farming (NCOF), Gaziabad (Anonymous, 2017).

- Fresh cow dung (500 g) and cow ghee (50 g) were mixed and poured in an earthen pot. This mixture was stored for three days and stirred two times a day during these three days, once in the morning and the other time in the evening. - Then, cow urine $(500 \mathrm{ml})$ and water $(500 \mathrm{ml})$ were mixed into this mixture. The mixture was stored for three days and stirred two times a day.

- After that, cow milk (100 ml), curd (100 g), jaggery (150 g) and a ripened banana by making a paste were added in the mixture. The mixture was stirred daily for 15 days and closed tightly, the panchagavya was ready and used for the experiment (Fig 1).

\section{Trichoderma spp.}

The effects of different Trichoderma spp. viz., T. viride, $T$. harzianum and $T$. asperellum were studied by dual culture technique (Dennis and Webster, 1971) against wilt complex causing pathogens separately. Trichoderma spp. isolates were obtained from the Department of Plant Pathology, BACA, Anand Agricultural University, Anand, the Department of Plant Pathology, CoA, Junagadh Agricultural University, Junagadh and the Department of Plant Pathology, NMCA, Navsari Agricultural University, Navsari for the experiment. Three repetitions were maintained for each antagonist. In control, the pathogen alone was inoculated at center. Observation on the radial growth was recorded from $24 \mathrm{hr}$. of the incubation at $28 \pm 1^{\circ} \mathrm{C}$ till the complete growth of test pathogen in control plates. The per cent growth inhibition (PGI) over control was calculated by using the formula given by Vincent (1947).

\section{RESULTS AND DISCUSSION}

\section{Panchagavya}

The antifungal effect of panchagavya on mycelial growth of fungal pathogens revealed that panchagavya exhibited significant inhibition of all the test organisms (Table 1 and Fig 2).

\section{F. oxysporum f. sp. ciceri}

Among the five different concentrations, panchagavya, $50 \%$ showed significantly maximum growth inhibition $(80.74 \%)$ with lowest fungal colony diameter $(17.33 \mathrm{~mm})$ which was at par with panchagavya, $40 \%(78.63 \%)$ with the colony diameter of $19.23 \mathrm{~mm}$. The next better antagonists in order of merit were as per the higher to lower concentration viz., $30,20 \%$ with 60.79 and 53.19 per cent growth inhibition, respectively. The least per cent growth inhibition was recorded with the lowest concentration of $10 \%(8.77 \%)$ with the colony diameter of $82.10 \mathrm{~mm}$.

\section{F. solani}

A similar trend was observed in mycelial growth inhibition of F. solani as it was observed in F. oxysporum f. sp. ciceri. At the lowest concentration $(10 \%)$, panchagavya was moderately effective as it inhibited the pathogen's growth by $7.87 \%$, while at the highest concentration $(50 \%)$ the growth inhibition was 66.62 per cent.

\section{M. phaseolina}

Panchagavya was moderately effective to inhibit the mycelial growth of $M$. phaseolina. At $50 \%$ concentration, panchagavya recorded maximum growth inhibition (49.67\%) with lowest fungal colony diameter $(45.30 \mathrm{~mm})$ followed by panchagavya, $40 \%(32.20 \%)$ with the colony diameter of $60.56 \mathrm{~mm}$, while at 10 and $20 \%$ concentration, it was not effective to inhibit the growth of $M$. phaseolina.

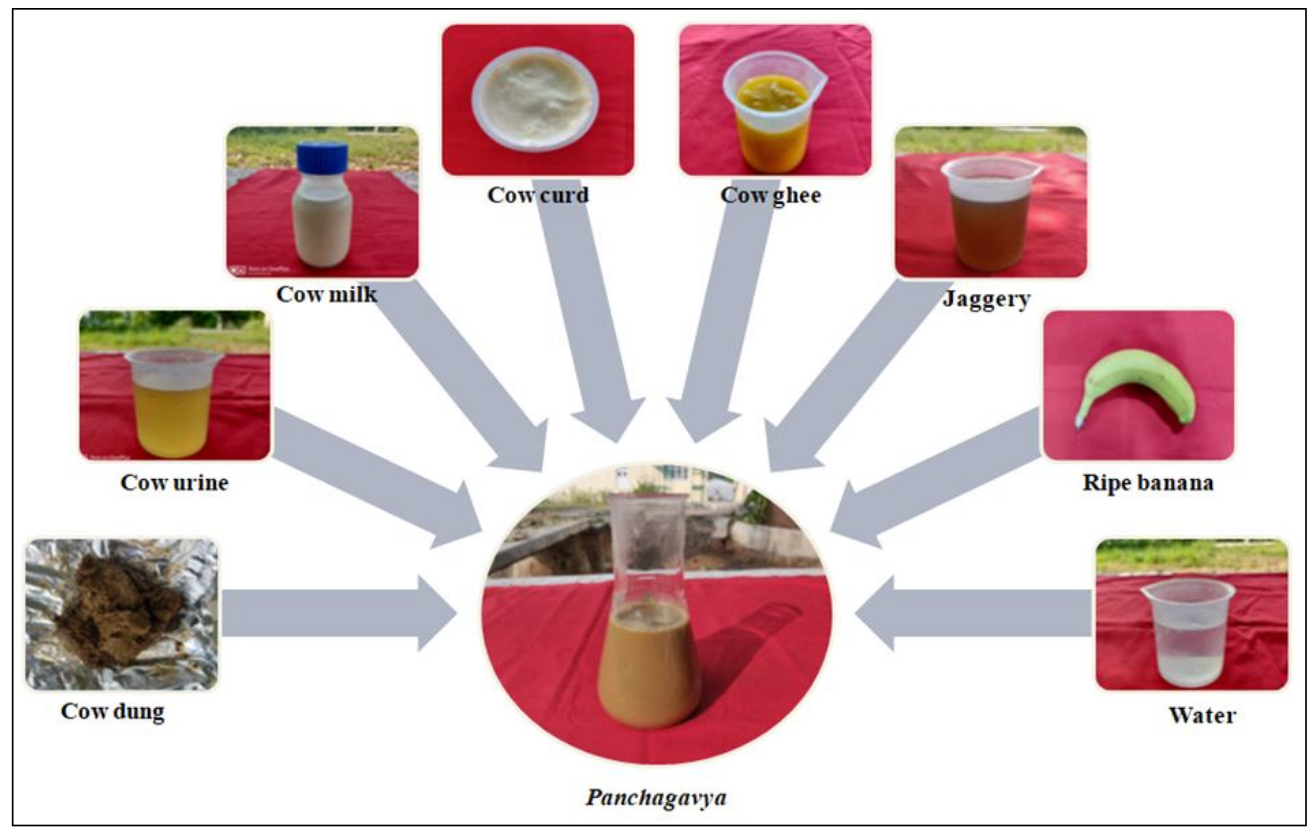

Fig 1: Ingredients used in the preparation of panchagavya. 
Indigenous agricultural practices, which are based on natural and organic methods of farming offer several feasible and effective solutions to most of the problems being faced in the conventional farming system. "Cow" plays a key role in most of the organic farming systems prevailing in Asian countries and elsewhere. In the present investigation, it has been contemplated that 'Panchagavya' contains growth-promoting hormones result in impressive yield and as immunity booster made the environment non-conducive for diseases.

Kumar et al. (2010) also found the effectiveness of panchagavya at the highest concentration (50\%), while moderately effective at the lowest concentration (5\%) against Pythium aphanidermatum causing damping-off in tomato. The above results were also in agreement with the findings of Jandaik and Sharma (2016), Kumar et al. (2018) and Rathore and Patil (2019) against F. oxysporum, F. solani, $R$. bataticola, $R$. solani and S. rolfsii.

\section{Trichoderma spp.}

The antagonistic effect of Trichoderma spp. revealed that all the tested isolates significantly reduced the radial mycelial growth of all the test pathogens (Table 2 and Fig 3 ).

\section{F. oxysporum f. sp. ciceri}

Trichoderma spp. inhibited mycelial growth in the range of 42.85 to 52.78 per cent over the control. Out of seven antagonists, $T$. viride (AAU isolate) was found significantly superior in growth inhibition $(52.78 \%)$ with lowest fungal colony diameter $(42.50 \mathrm{~mm})$ of $F$. oxysporum f. sp. ciceri followed by $T$. viride (JAU isolate) $(49.63 \%)$ with the colony diameter of $45.33 \mathrm{~mm}$ and T. viride (NAU isolate) $(48.89 \%)$ with the colony diameter of $46.00 \mathrm{~mm}$. The least growth inhibition was recorded with $T$. harzianum (NAU isolate) $(42.85 \%)$ with the colony diameter of $51.43 \mathrm{~mm}$.

\section{F. solani}

All the antagonists tested have shown a significant reduction of the radial mycelial growth of $F$. solani to the extent of 55.56 to 65.37 per cent as compared to control. Out of seven antagonists, $T$. viride (AAU isolate) showed significantly maximum growth inhibition $(65.37 \%)$ with lowest colony diameter $(31.17 \mathrm{~mm})$ of $F$. solani which was at par with $T$. harzianum (JAU isolate) $(64.44 \%)$ with the colony diameter of $32.00 \mathrm{~mm}$.

Table 1: In vitro evaluation of panchagavya against wilt complex causing pathogens.

\begin{tabular}{|c|c|c|c|c|c|c|c|}
\hline \multirow[b]{2}{*}{ Tr. no. } & \multirow[b]{2}{*}{ Treatments } & \multicolumn{2}{|c|}{ F. oxysporum f. sp. ciceri } & \multicolumn{2}{|c|}{ F. solani } & \multicolumn{2}{|c|}{ M. phaseolina } \\
\hline & & $\begin{array}{l}\text { Mycelial growth } \\
\text { of pathogen } \\
(\mathrm{mm})\end{array}$ & $\begin{array}{c}\text { Growth } \\
\text { inhibition } \\
(\%)\end{array}$ & $\begin{array}{l}\text { Mycelial growth } \\
\text { of pathogen } \\
(\mathrm{mm})\end{array}$ & $\begin{array}{c}\text { Growth } \\
\text { inhibition } \\
(\%)\end{array}$ & $\begin{array}{l}\text { Mycelial growth } \\
\text { of pathogen } \\
(\mathrm{mm})\end{array}$ & $\begin{array}{c}\text { Growth } \\
\text { inhibition } \\
(\%)\end{array}$ \\
\hline $\mathrm{T}_{1}$ & Panchagavya, $10 \%$ & 82.10 & 8.77 & 82.92 & 7.87 & 88.65 & 1.50 \\
\hline $\mathrm{T}_{2}$ & Panchagavya, $20 \%$ & 42.13 & 53.19 & 46.12 & 48.75 & 85.40 & 5.11 \\
\hline $\mathrm{T}_{3}$ & Panchagavya, $30 \%$ & 35.29 & 60.79 & 42.14 & 53.18 & 80.39 & 10.68 \\
\hline $\mathrm{T}_{4}$ & Panchagavya, $40 \%$ & 19.23 & 78.63 & 33.81 & 62.43 & 60.56 & 32.20 \\
\hline $\mathrm{T}_{5}$ & Panchagavya, $50 \%$ & 17.33 & 80.74 & 30.04 & 66.62 & 45.30 & 49.67 \\
\hline \multirow[t]{4}{*}{$\mathrm{T}_{6}$} & Control (Test pathogen only) & 90.00 & - & 90.00 & 0.00 & 90.00 & 0.00 \\
\hline & S.Em \pm & - & 0.98 & - & 1.12 & - & 0.43 \\
\hline & C.D. at $5 \%$ & - & 3.03 & - & 3.46 & - & 1.33 \\
\hline & C.V. \% & - & 3.62 & - & 4.88 & - & 4.54 \\
\hline
\end{tabular}

Table 2: In vitro evaluation of Trichoderma spp. against wilt complex causing pathogens.

\begin{tabular}{|c|c|c|c|c|c|c|c|}
\hline \multirow[b]{2}{*}{ Tr. no. } & \multirow[b]{2}{*}{ Antagonists } & \multicolumn{2}{|c|}{ F. oxysporum f. sp. ciceri } & \multicolumn{2}{|c|}{ F. solani } & \multicolumn{2}{|c|}{ M. phaseolina } \\
\hline & & $\begin{array}{l}\text { Mycelial growth } \\
\text { of pathogen } \\
(\mathrm{mm})\end{array}$ & $\begin{array}{c}\text { Growth } \\
\text { inhibition } \\
(\%)\end{array}$ & $\begin{array}{l}\text { Mycelial growth } \\
\text { of pathogen } \\
(\mathrm{mm})\end{array}$ & $\begin{array}{c}\text { Growth } \\
\text { inhibition } \\
(\%)\end{array}$ & $\begin{array}{l}\text { Mycelial growth } \\
\text { of pathogen } \\
(\mathrm{mm})\end{array}$ & $\begin{array}{c}\text { Growth } \\
\text { inhibitior } \\
(\%)\end{array}$ \\
\hline $\mathrm{T}_{1}$ & T. viride (AAU isolate) & 42.50 & 52.78 & 31.17 & 65.37 & 38.00 & 57.78 \\
\hline $\mathrm{T}_{2}$ & T. viride (JAU isolate) & 45.33 & 49.63 & 38.17 & 57.59 & 39.00 & 56.67 \\
\hline $\mathrm{T}_{3}$ & T. viride (NAU isolate) & 46.00 & 48.89 & 40.00 & 55.56 & 42.33 & 52.96 \\
\hline $\mathrm{T}_{4}$ & T. harzianum (AAU isolate) & 49.50 & 45.00 & 35.33 & 60.74 & 42.67 & 52.59 \\
\hline $\mathrm{T}_{5}$ & T. harzianum (JAU isolate) & 49.67 & 44.82 & 32.00 & 64.44 & 44.00 & 51.11 \\
\hline$T_{6}$ & T. harzianum (NAU isolate) & 51.43 & 42.85 & 34.33 & 61.85 & 34.67 & 61.48 \\
\hline $\mathrm{T}_{7}$ & T. asperellum (AAU isolate) & 50.00 & 44.44 & 37.00 & 58.89 & 30.67 & 65.93 \\
\hline \multirow[t]{4}{*}{$\mathrm{T}_{8}$} & Control (Test pathogen only) & 90.00 & - & 90.00 & - & 90.00 & - \\
\hline & S.Em \pm & - & 0.99 & - & 0.71 & - & 1.09 \\
\hline & C.D. at $5 \%$ & - & 2.98 & - & 2.13 & - & 3.29 \\
\hline & C.V. \% & - & 4.20 & - & 2.32 & - & 3.81 \\
\hline
\end{tabular}




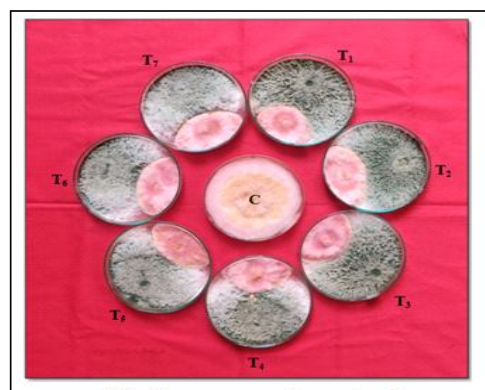

(A) F. oxysporum f. sp. ciceri

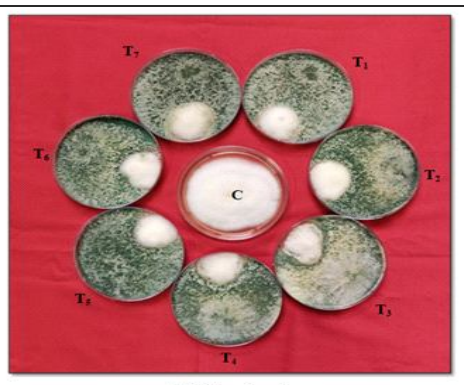

(B) F. solani

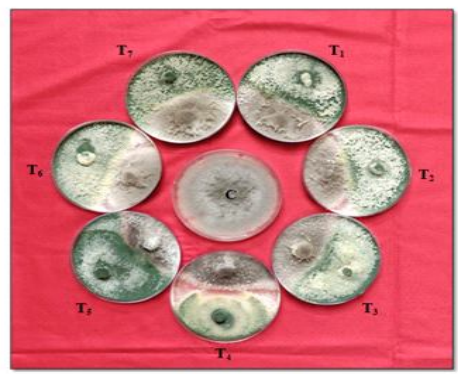

(C) M. phaseolina

Fig 2: In vitro evaluation of Trichoderma spp. against wilt complex causing pathogens.

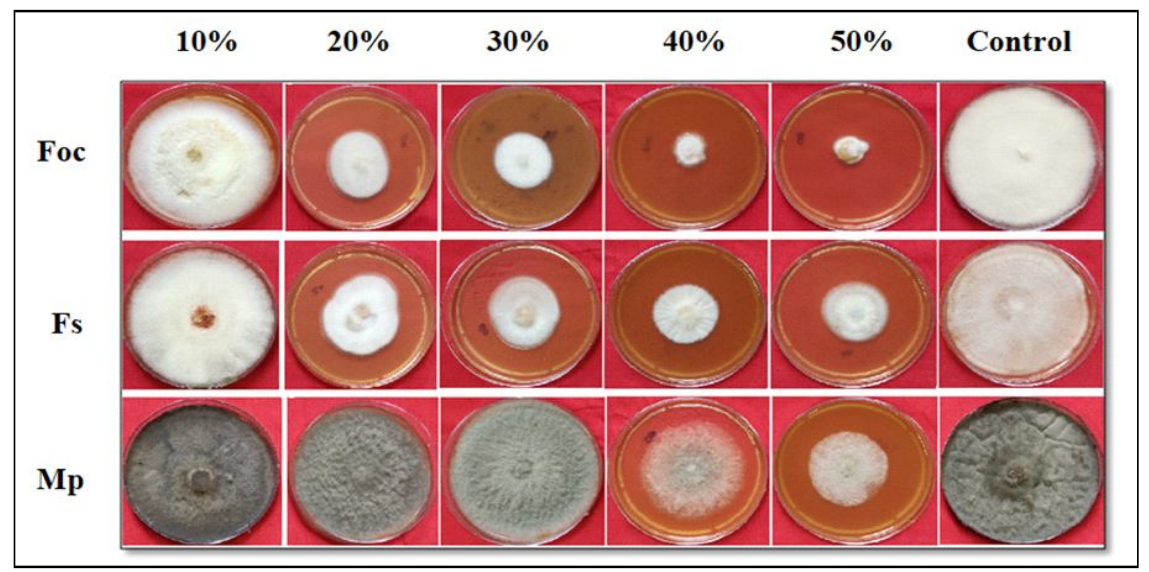

Fig 3: In vitro evaluation of panchagavya against wilt complex causing pathogens.

\section{M. phaseolina}

The maximum per cent growth inhibition (65.93\%) of the pathogen was observed in $T$. asperellum with lowest colony diameter $(30.67 \mathrm{~mm})$, while the next better was T. harzianum (NAU isolate) $(61.48 \%)$ with the colony diameter of 34.67 $\mathrm{mm}$. The next better antagonists in order of merit were $T$. viride (AAU isolate), T. viride (JAU isolate), T. viride (NAU isolate), T. harzianum (AAU isolate) and T. harzianum (JAU isolate) with growth inhibition of $57.78,56.67,52.96,52.59$ and $51.11 \%$, respectively.

Biocontrol agents are the balance wheel in nature, where there is life there is antagonism. Domestic isolates are the most virulent strains because of their persistent capability under the soil and local climatic conditions.

Similarly andrabi et al. (2011), Chanu et al. (2018), Lakhran and Ahir (2020) and Khanna et al. (2021) also evaluated Trichoderma spp. against chickpea soil-borne pathogens viz., F. oxysporum f. sp. ciceri, F. solani, R. solani and $S$. rolfsii and reported $T$. viride as most effective in inhibiting mycelial growth of the pathogens. The present findings are also in harmony with earlier workers viz., Dhedhi et al. (1990), Devika Rani et al. (2009) and Nagamani et al. (2018).

\section{CONCLUSION}

In nutshell, with an increase in the concentration of the panchagavya, there was a corresponding increase in the inhibition of mycelial growth of the fungal pathogens. All the Trichoderma spp. were effective in reducing the mycelial growth of chickpea wilt complex pathogens. Further, T. viride isolates were superior in inhibiting the growth of Fusarium spp. and $T$. asperellum isolate was significant in inhibiting the growth of $M$. phaseolina. 


\section{REFERENCES}

Andrabi, A., Vaid, A. and Razdan, V.K. (2011). Evaluation of different measures to control wilt causing pathogens in chickpea. Journal of Plant Protection Research. 51(1): 55-59.

Anonymous (2017). Organic Agriculture-Concept, Scenario, Principals and Practices. National Centre of Organic Farming Department of Agriculture and Cooperation, Ministry of Agriculture, Govt of India, Ghaziabad, Uttar Pradesh, pp. 25.

Chanu, W., Sinha, B., Devi, P.H., Devi, N.O. and Devi, H.C. (2018). Molecular identification of pathogens associated soilborne diseases of chickpea and their management by native Trichoderma spp. Plant Disease Research. 33(1): 50-59.

Cother, E.J. (1977). Identification and control of root rot fungi in Cicer arietinum (Chickpea). Plant Dis. Rep. 61: 736-74.

Dennis, C. and Webster, J. (1971). Antagonistic properties of species group of Trichoderma production of non-volatile antibiotics. Transactions of the British Mycological Society. 57: 25-39.

Devika Rani, G.S., Naik, M.K., Patil, M.B. and Prasad, P.S. (2009). Biological control of Fusarium solani causing wilt of chilli. Indian Phytopathology. 62(2): 190-198.

Dhedhi, B.M., Gupta, O. and Patel, V.A. (1990). Antagonistic effect of microorganisms to Fusarium oxysporum f. sp. ciceri. Journal of Mycology and Plant Pathology. 24: 120-127.

Grover, R.K. and Moore, J.D. (1962). Toximetric studies of fungicides against the brown rot organisms, Sclerotinia fruticola and S. laxa. Phytopathology. 52: 876-880.

Jandaik, S. and Sharma, V. (2016). Antifungal potential of panchagavya against soil-borne fungal pathogens associated with Capsicum nurseries. International Invention Journal of Agricultural and Soil Science. 4(2): 22-26.

Khanna, A., Raj, K. and Kumar, P. (2021). Construing the Role of Plant Extracts, Fungicides and Bio-agents in Ameliorating Fusarium Wilt Management in Chickpea. Legume Research. DOI: $10.18805 /$ LR-4637.
Kumar, R.S., Srinivas, T., Kumari, P.V. and Kumar, S.R. (2018). In vitro studies on dry root rot in chickpea by using fungicides, natural farming products and organic amendments. International Journal of Chemical Studies. 6(5): 3334-3338.

Kumar, R., Hooda, I. and Karwasra, S.S. (2010). Efficacy of mahapanchagavya (MPG) in controlling damping-off in tomato caused by Pythium aphanidermatum. Bangladesh Journal of Agricultural Research. 35(1): 11-16.

Lakhran, L. and Ahir, R.R. (2020). In vivo evaluation of different fungicides, plant extracts, bio-control agents and organics amendments for management of dry root rot of chickpea caused by Macrophomina phaseolina. Legume Research. 43: $140-145$.

Munshi, K.M. (1964). Agriculture in ancient India. Monograph, ICAR. New Delhi, pp. 84-100.

Nagamani, P., Bhagat, S., Vishwanath, K. and Biswas, M.K. (2018). Molecular characterization of antagonistic Trichoderma isolates against soil-borne pathogens of chickpea. Journal of Mycology and Plant Pathology. 48(3): 303-310.

Natarajan, K. (2002). Panchagavya: A manual, India Press, Mapusa, Goa. pp. 33.

Nene, Y.L., Sheila, V.K. and Sharma, S.B. (1996). A World List of Chickpea and Pigeonpea Pathogens. $5^{\text {th }}$ Ed., ICRISAT, Patancheru, India. pp. 27.

Rathore, M.S. and Patil, A.D. (2019). Panchagavya, an organic amendment for inhibiting damping-off causing Fusarium solani and Sclerotium rolfsii under in vitro conditions. Indian Journal of Pure and Applied Biosciences. 7(4): 203-206.

Sharma, P., Sharma, M., Raja, M. and Shanmugam, V. (2014). Status of Trichoderma research in India: A review. Indian Phytopathology. 67(1): 1-19.

Vincent, J.M. (1947). Distortion of fungal hyphae in the presence of certain inhibitor. Nature. pp. 159-850. 